\title{
HAK WARIS BAGI AHLI WARIS YANG TIDAK DAPAT DITENTUKAN KEBERADAANNYA MENURUT KITAB UNDANG-UNDANG HUKUM PERDATA
}

\author{
Anak Agung Krisna Kumala Dewi, I Nyoman Putu Budiartha, Diah Gayatri Sudibya \\ Fakultas Ilmu Hukum Universitas Warmadewa, Denpasar - Bali, Indonesia
}

\begin{abstract}
Abstrak
Ahli waris yang tidak dapat ditentukan keberadaannya adalah ahli waris yang kehilangan kabar sehingga tidak diketahui apakah dia masih hidup atau sudah mati. Ini biasanya disebut orang hilang. Namun nyatanya banyak ahli waris yang mengabaikan hak waris daari ahli waris yang tidak dapat ditentukan keberadaannya. Berdasarkan latar belakang tersebut penelitian ini dilakukan dengan tujuan menguraikan pengaturan hak waris bagi ahli waris yang tidak dapat ditentukan keberadaannya dan akibat hukum terhadap ahli waris yang diketahui keberadaannya setelah harta warisannya dibagi. Penelitian ini menggunakan metode penelitian hukum normatif dengan pendekatan perundang-undangan dan pendekatan konseptual. Hasil penelitian ini menunjukkan bahwa hak waris bagi ahli waris yang belum bisa ditentukan keberadaannya diatur dalam Pasal 463 KUH Perdata. Hak waris ahli waris yang tidak dapat ditentukan keberadaannya tetap melekat padanya sesuai dengan ketentuan Pasal 467 KUH Perdata. Namun, selama ahli waris tidak diketahui keberadaannya maka jabatan tersebut akan digantikan oleh ahli waris penerus. Selanjutnya, akibat hukum setelah ahli waris diketahui ada, ahli waris pengganti wajib mengembalikan semua harta warisan yang diterima berdasarkan ketentuan Pasal 482 ayat (1) KUH Perdata.
\end{abstract}

Kata Kunci: Ahli Waris; Keadaan Tak Hadir; Warisan

\begin{abstract}
The heirs whose whereabouts cannot be determined are the heirs who have lost the news, so it is not known whether he is alive or dead. These are usually called missing persons. However, in fact, a lot of heirs ignore the inheritance rights of an heir whose existence cannot be determined. Based on this background, this research was conducted with the aim of elaborating the arrangement of inheritance rights for heirs whose existence cannot be determined and the legal consequences for heirs whose existence is known after the inheritance is divided. This study used a normative legal research method with a statutory and conceptual approach. The results of this study showed that the existence of inheritance rights for heirs that cannot be determined is regulated in Article 463 of the Civil Code. The inheritance rights of heirs whose existence cannot be determined remain attached to it in accordance with the provisions of Article 467 of the Civil Code. However, as long as the whereabouts of the heir are not known, the position will be replaced by the successor heirs. Furthermore, as a legal consequence after an heir is known to exist, the replacement heir is obliged to return all the inherited assets received under the provisions of Article 482 paragraph (1) of the Civil Code.
\end{abstract}

Keywords: Heir; Absence; Inheritance

\section{PENDAHULUAN}

Di Indonesia masih banyak terjadi pluralisme hukum yang menyangkut mengenai pemasalahan hukum waris. Akan tetapi secara umum dan menyeluruh, pedoman yang digunakan terhadap permasalahan mengenai waris adalah Kitab Undang-Undang Hukum Perdata atau dalam Bahasa Belanda disebut Burgelijk Wetboek. Berbicara mengenai waris, hukum waris adalah ketentuankentuan yang mengatur nasib kekayaan orang setelah pemiliknya meninggal dunia (Djamali, 2010). Dalam pewarisan terdapat tiga unsur penting yaitu: peninggal harta warisan atau disebut pewaris, harta yang ditinggalkan atau disebut harta warisan, dan si penerima warisan atau disebut ahli waris (Artadi, 2012).

Yang menjadi objek dalam hukum waris adalah harta kekayaan si pewaris yang nantinya akan dibagi bersama antara para ahli waris baik berdasarkan Undang-Undang atau berdasarkan wasiat. 
Dalam Pasal 838 KUHPerdata menyebutkan bahwa ada empat hal yang menyebabkan ahli waris tidak patut menerima warisan yaitu:

1. Ahli waris karena putusan hakim dihukum karena mencoba membunuh pewaris,

2. Ahli waris kerena putusan hakim dihukum karena memfitnah pewaris melakukan kejahatan,

3. Ahli waris yang dengan kekerasan menghalangi pewaris untuk membuat wasiat, dan

4. Ahli waris yang memusnahkan surat wasiat.

Dari syarat tersebut tidak ada yang membahas mengenai ahli waris yang tidak dapat diketahui keberadaannya. Ahli waris yang tidak dapat diketahui keberadaannya dapat juga dikatakan sebagai ahli waris dalam keadaan tak hadir (Bidasari, 2016; Canggayuda, Rahayu, \& Haswaningrum, 2015; Heriyani \& Yuniarlin, 2019). Mengenai ahli waris yang dalam keadaan tak hadir tersebut diatur dalam Buku Kesatu BAB XVIII Pasal 463 tentang Keadaan Tak Hadir (Sihombing, Firdaus, \& Fitriani, 2016; Tanuwidjaja, 2019). Dalam hal ini terjadi suatu kekaburan norma. Kekaburan norma hukum artinya adanya suatu norma yang tidak jelas yang dapat menimbulkan pernafsiran berbeda dari norma tersebut, atau aturannya ada tetapi keberadaan aturan tersebut tidak diterapkan secara baik.

Dari uraian singkat latar belakang masalah tersebut, penelitian ini dilakukan dengan tujuan menguraikan bagaimana pengaturan hak waris bagi ahli waris yang tidak dapat ditentukan keberadaannya dan apa akibat hukum terhadap ahli waris yang diketahui keberadaannya setelah harta warisannya dibagi.

\section{METODE PENELITIAN}

Penelitian ini didesain dengan menggunakan metode penelitian hukum normatif dengan menggunakan pendekatan Peraturan Perundang-Undangan dan Pendekatan Konseptual. Sumber bahan hukum yang digunakan yaitu bahan hukum primer dan bahan hukum sekunder. Bahan hukum primer bersumber pada Kitab Undang-Undang Hukum Perdata. Bahan hukum sekunder bersumber pada buku atau literatur lainnya seperti jurnal-jurnal huku, kamus-kamus hukum sebagai penunjang isu hukum yang dibahas. Teknik pengumpulan bahan hukum yang digunakan dalam penelitian ini yaitu teknik studi kepustakaan dengan melakukan pencarian melalui internet sesuai dengan isu hukum yang dibahas. Analisis bahan hukum yang digunakan adalah teknik konstruksi hukum dan argumentasi hukumi. Setelah itul hasil penelitian ini disajikan secara deskriptif.

\section{HASIL DAN PEMBAHASAN}

\section{Pengaturan Hak Waris bagi Ahli Waris yang Tidak Dapat Ditentukan Keberadaannya}

Yang menjadi pedoman mengenai permasalahan waris di Indonesia yaitu Kitab Undang-Undang Hukum Perdata diatur dalam Pasal 830 yang menyebutkan "pewarisan terjadi karena kematian". Hukum waris merupakan seperangkat kaidah hukum yang mengatur pemindahaan harta kekayaan dari si peninggal harta warisan (pewaris) kepada sekalian ahli warisnya karena meninggalnya si pewaris (Pitlo, 1986). Dari pemindahan harta warisan tersebut maka akan timbul suatu akibat hukum bagi ahli waris yang memperoleh warisan tersebut dan juga bagi mereka dalam hubungannya dengan pihak ketiga. Unsur terpenting dalam hukum waris yaitu si pewaris, harta warisan dan ahli waris.

Mengenai hal tersebut, maka yang dimaksud dengan hak waris adalah suatu hak yang diperoleh oleh ahli waris untuk menerima atau menguasi harta warisan yang ditinggalkan oleh si pewaris tetapi harus atas kehendak si pewaris. Terkait dengan hak waris bagi ahli waris yang tidak dapat ditentukan keberadaannya yang dalam keadaan tak hadir, hail ini diatur secara khusus dalam KUHPerdata yaitu dalam Buku Kesatu Bab XVIII Tentang Keadaan Tak hadir Pasal 463. Yang dimaksud dengan orang yang tidak dapat ditentukan keberadaannya adalah seseorang yang pergi meninggalkan kediamannya baik dengan izin maupun tanpa izin dan sekarang tidak diketahui apakah orang tersebut sudah meninggal atau masih hidup (Syariffudin, 2005). Orang yang tidak dapat ditentukan keberadaannya tersebut juga dapat dikatakan sebagai orang hilang.

Dengan demikian sesuai pengertian hak waris tersebut maka hak waris bagi ahli waris yang tidak dapat ditentukan keberadaannya telah ia peroleh dalam kandungan Ibunya dan dianggap dilahirkan. Berdasarkan Pasal 830 maka sejak itu ahli waris telah berhak mewarisi harta warisan si pewaris. Dalam Pasal 463 mengatur mengenai orang-orang yang diperkirakan telah meninggal dunia yang menyebutkan bahwa seseorang yang telah meninggalkan kediamannya tanpa memberi kuasa kepada seorang wakil maka atas jawatan kejaksaan, Pengadilan negeri setempat memerintah Balai Harta Peninggalan untuk mengurus harta kekayaannya dan mengurus segala kepentingannya dan bila 
kembali pulang maka seluruh hak-haknya agar diberikan kepada yang tak hadir tersebut. Selain itu, dalam Pasal 467 KUHPerdata menjelaskan mengenai orang yang diperkirakan meninggal setelah lima tahun setelah kabar terakhirnya, maka pengadilan setempat berhak memanggil orang lain untuk membuktikan bahwa orang yang tak hadir itu masih hidup. Dengan pemanggilan yang dilakukan sampai ketiga kalinya, jika tidak ada tanda-tanda bahwa si pwearis tak hadir tersebut masih hidup, maka Pengadilan berhak mengeluarkan Keputusan bahwa dugaan yang tak hadir tersebut telah meninggal dunia. Hal ini juga harus termuat dalam surat kabar sesuai dengan ketentuan Pasal 468 KUHPerdata.

Di samping itu, perlu juga adanya suatu perlindungan hukum bagi ahli waris yang tidak dapat ditentukan keberadaannya. Menurut Satjipto Raharjo, perlindungan hukum adalah memberikan pengayoman kepada hak asasi manusia yang dirugikan orang lain, dan perlindungan tersebut diberikan kepada masyarakat agar mereka dapat menikmati semua hak-hak yang diberikan oleh hukum. Mengenai perlindungan hukum bagi ahli waris yang dalam keadaan tak hadir tersebut mengingat sesuai dengan Ketentuan pasal 463 KUHPerdata haknya masih dapat diperjuangkan sebagai ahli waris. Dan, dalam ketentuan Pasal 467 KUHPerdata juga memberikan suatu kepastian hukum akan hak hidup seorang ahli waris yang dalam keadaan tak hadir tersebut.

\section{Akibat Hukum terhadap Ahli Waris yang Diketahui Keberadaannya setelah Harta Warisannya Dibagi}

Ada 3 unsur mengenai kedudukan ahli waris yaitu: hak dan kewajiban beralih seketika kepada ahli waris pada saat ahli waris meninggal dunia; hak istimewa artinya ahli waris memiliki hak untuk menuntut agar diserahkan boedel warisan yang berada pada pihak ketiga; dan peralihan warisan kepada ahli waris berupa aktiva dan pasiva dari pewaris dengan menyatakan menerima warisan.

Menurut KUHPerdata diatur mengenai orang-orang yang terhalang mendapatkan harta warisan yaitu:

1. Suami atau istri yang bercerai,

2. Ahli waris yang menolak warisan, dan

3. Orang yang menggantikan ahli waris yang menolak warisan.

Selain itu KUHPerdata juga mengatur mengenai golongan hali waris yang dibagi menjadi empat golongan yaitu :

1. Golongan Pertama yaitu dalam garis lurus kebawah, meliputi anak-anak beserta keturunannya tanpa membedakan jenis kelamin, waktu kelahiran dari perkawinan pertama dan kedua. Kemudian suami atau istri yang hidup paling lama.

2. Golongan Kedua yaitu keluarga dalam garis lurus keatas meliputi orang tua, saudara laki-laki dan perempuan dan keturunannya.

3. Golongan Ketiga yaitu terdiri keluarga sedarah dalam garis lurus keatas jika si pewaris tidak meninggalkan keturunan maupun suami atau istri, saudara-saudara atau keturunan saudarasaudara, maka yang mendapat giliran adalah keluarga sedarah selanjutnya didalam garis lurus keatas yang disebut golongan ketiga.

4. Golongan Keempat yaitu keluarga lainnya dalam garis menyamping yang dibatasi dengan derajat keenam baik dari pihak bapak atau pihak ibu.

Selain pembagian golongan tersebut maka dalam KUHPerdata juga dikenal ada dua macam ahli waris yaitu:

1. Ahli waris karena kedudukannya sendiri yaitu ahli waris yang dilahirkan dari suatu perkawinan yang sama atau berbeda yang secara langsung mewaris terhadap kedua orang tuanya, dalam garis lurus keatas,

2. Ahli waris karena penggantian tempat yaitu orang yang menggantikan kedudukan ahli waris yang sebenarnya karena ahli waris tersebut terlebih dahulu meninggal daripada si pewaris.

Mengenai permasalahan ahli waris yang tidak dapat ditentukan keberadaannya dengan adanya suatu putusan yang menyatakan bahwa ada dugaan bahwa ahli waris yang dalam keadaan tak hadir tersebut meninggal dunia, maka seketika itu jika pewarisnya meninggal dunia, kedudukannya digantikan oleh ahli waris pengganti. Penggantian tempat ini memberikan hak dan kewajiban kepada ahli waris pengganti untuk menggantikan orang yang ia gantikan kedudukannya. Mengenai penggantian tersebut diatur dalam Pasal 841 KUHPerdata. Menurut Pasal 468 KUHPerdata menyebutkan bahwa setelah putusan pengadilan yang menyatakan bahwa yang tak hadir tersebut ada 
dugaan meninggal dunia maka seketika itu kedudukannya akan digantikan oleh ahli waris pengganti. Yang berhak sebagai ahli waris pengganti yaitu suami atau istri yang ditinggal oleh si yang tak hadir tersebut atau anak dari si yang tak hadir atau juga keluarga sedarah dari si yang tak hadir tersebut sesuai pembagian berdasarkan pancang demi pancang.

Selain itu permasalah mengenai akibat hukum bagi ahli waris yang tidak dapat ditentukan keberadaannya tersebut kembali pulang, haknya sebagai ahli kembali pulang apabila belum adanya putusan pengadilan yang menyatakan ahli waris yang dalam keadaan tak hadir tersebut meninggal dunia. Oleh karena itu, ahli waris yang tidak dapat ditentukan keberadaannya tersebut masih berhak atas segala bentuk harta warisan saat dia pulang kembali. Namun, apabila ahli waris yang tidak dapat tidak dapat ditentukan keberadaannya kembali pulang dan tidak mendapatkan hak-haknya terhadap warisan tersebut, maka ahli waris tersebut berhak untuk melakukan tuntutan terhadap tiap-tiap orang yang menikmati harta warisan tersebut untuk mengembalikannya kepada ahli waris yang telah diketahui keberadaannya setelah kembali pulang sesuai dengan ketentuan Pasal 476 KUHPerdata. Namun apabila ahli waris yang tidak dapat ditentukan keberadaannya tersebut kembali pulang setelah melampaui tiga puluh tahun sejak Keputusan Hakim bahwa dugaan ahli waris yang tak hadir tersebut meninggal, maka ahli waris tersebut hanya dapat menuntut kembali barang-barang yang telah dipindahtangankan atau barang-barang yang telah dibeli dengan hasil pemindahtangan barang-barang kepunyaannya. Namun semuanya tanpa hasil atau pendapatan sesuai dengan ketentuan Pasal 486 KUHPerdata.

\section{SIMPULAN DAN SARAN \\ 1. Simpulan}

Berdasarkan hasil dan pembahasan di atas, ada beberapa simpulan yang dapat dibuat, yaitu: pertama, pengaturan mengenai hak waris bagi ahli waris yang tidak dapat ditentukan keberadaannya diatur dalam Pasal 463 KUHPerdata yang yang secara garis besar menentukan bahwa jika orang yang tidak dapat ditentukan keberadaannya tersebut pergi tanpa memberi Kuasa kepada seorang wakil, maka seluruh harta peninggalannya akan diurus oleh Balai Harta Peninggalan atau menunjuk keluarga sedarah, dan jika ahli waris yang tidak dapat ditentukan keberadaannya tersebut kembali pulang maka, keluarga atau istri/suami yang tak hadir tersebut harus mengembalikan harta kekayaan yang ditinggalkan kepadanya. Dalam KUHPerdata hak mewaris bagi ahli waris yang tidak dapat ditentukan keberadaannya tentunya masih melekat terhadap ahli waris tersebut yang diatur dalam Pasal 463, 467 KUHPerdata, kecuali Pengadilan memutus bahwa ada dugaan bahwa ahli waris yang tidak dapat ditentukan keberadaannya dalam keadaan tak hadir tersebut telah meninggal dunia. Kedua, akibat hukum bagi ahli waris yang telah diketahui keberadaannya setelah harta warisannya dibagi, dia berhak untuk melakukan tuntutan terhadap tiap-tiap orang yang menikmati harta warisan tersebut. Hal ini diatur dalam Pasal 482 ayat (1) yang secara garis besar menyebutkan bahwa jika orang yang tidak dapat ditentukan keberadaannya itu kembali pulang setelah ada keterangan kematian dugaan maka bagi mereka yang telah menikmati tiap-tiap dari hasil harta kekayaan yang tak hadir tersebut wajib mengembalikan setengah dari pendapatannya setelah ia kembali pulang, tetapi sebelum lampau tiga puluh tahun setelah Putusan Pengadilan yang menyatakan orang yang tidak dapat ditentukan keberadaannya tersebut meninggal dunia.

\section{Saran}

Ada juga saran yang perlu disampaikan kepada beberapa pihak berdasarkan hasil penelitian ini, yaitu: pertama, bagi aparat penegak hukum agar memberikan perlindungan hukum bagi ahli waris yang tidak dapat ditentukan keberadaannya atas harta kekayaan yang ditinggalkannya. Kedua, bagi pewaris agar tetap memperhatikan ketentuan KUHPerdata agar hak waris bagi ahli waris yang tidak dapat ditentukan keberadaannya yang dalam keadaan tak hadir tersebut hak warisnya tetap ia peroleh jika si tak hadir tersebut kembali pulang, sehingga tidak terjadinya suatu kekaburan norma hukum.

\section{DAFTAR PUSTAKA}

Artadi, I. ketut. (2012). Hukum Adat Bali dengan Aneka Masalahnya (VI). Denpasar: Pustaka Bali Post.

Bidasari, A. (2016). Eksistensi Kewenangan Balai Harta Peninggalan atas Orang yang Dinyatakan Tidak Hadir (Afwezigheid). Jurnal Panorama Hukum, 1(2), 29-42.

Canggayuda, J., Rahayu, H. S. P., \& Haswaningrum, A. (2015). Analisis Yuridis Kedudukan Orang Hilang dalam Kewarisan Berdasarkan Kitab Undang-Undang Hukum Perdata. Privat Law, 136- 
142.

Djamali, R. A. (2010). Pengantar Hukum Indonesia. Jakarta: PT Raja Grafindo Persada.

Heriyani, E., \& Yuniarlin, P. (2019). Perlindungan Hukum bagi Ahli Waris yang Tidak Hadir (Afwezig) dalam Pembagian Harta Warisan di DIY. Transparansi Hukum, 2(1), 17-30.

Pitlo, M. A. (1986). Hukum Waris Menurut Kitab Undang-Undang Hukum Perdata Belanda (1st ed.). Jakarta: PT Intermesa.

Sihombing, M. A. B., Firdaus, \& Fitriani, R. (2016). Peralihan Hak dan Kepemilikan Harta Kekayaan yang Tidak Diketahui Pemilik dan Ahli Warisnya di Balai Harta Peninggalan Kota Medan. JOM Fakultas Hukum Universitas Riau, 3(2), 1-15.

Syariffudin, A. (2005). Hukum Kewarisan Islam. Jakarta: Prenada Media.

Tanuwidjaja, T. H. (2019). Akibat Hukum Pewarisan karena Afwezeigheid terhadap Ahli Waris Menurut Hukum Perdata Barat (B.W). Hukum Bisnis, 3(1), 21-34. 